\title{
The Attitudes of Physiotherapy Students Toward Occupational Medicine
}

\author{
Dr. Henrrik Prendushi \\ Department of Nursery/Physiotherapy, Faculty of Natural Sciences, \\ University of Shkodra "Luigj Gurakuqi" Albania.
}

doi: 10.19044/esj.2016.v12n36p39 URL:http://dx.doi.org/10.19044/esj.2016.v12n36p39

\begin{abstract}
Diseases and work-related injuries make an important part in the global burden of disease. These are studied, prevented and treated by occupational professionals as well as other health care professionals. Physiotherapists have an important role in rehabilitation of the people suffering from different workrelated injuries and diseases. Our study aims to know the attitudes of the students of Physiotherapy regarding the Occupational Medicine, in its general character, as well as their perceptions about the Albanian reality, the future of this medical science in Albania, and the relations with their profession. An anonymous questionnaire was distributed to the third year students of Physiotherapy at the University Luigj Gurakuqi in Shkodra, in their first lesson of Occupational Medicine. It consisted of 23 questions, some of them in the form of a 5 point Likert. The questionnaire was made in two parts: demographic data and the research data. The questionnaire was completed by 31 students. There is a good level of knowledge of foreign languages, 27 of them know English. The need to study the subject resulted in 3.90 points on a 5 point Likert. The degree of awareness of occupational medicine in Albania resulted in 2.03 points and the implementation of the laws in just 1.90 points, but more than $90 \%$ of the students affirm that there is an increased interest on occupational medicine during last 5 years in the country. They unanimously agree about the relationships between their profession and the occupational medicine. The majority of the students are interested about more training, and for more than one half it is a career option, too.
\end{abstract}

Keywords: Occupational medicine, Albania, physiotherapy, health and safety, students`attitudes.

\section{Introduction}

Diseases and work-related injuries have an important part in the global burden of disease. According to estimates of the International Labour 
Organization (ILO), about two million workers worldwide die every year from injuries and work-related diseases (http://www.ilo.org). The number of deaths is higher in men, with two-thirds of deaths, and the main diseases are cancer, the circulatory diseases and infectious diseases (Hämäläinen, Saarela \& Takala, 2013; Manickam et al., 2014; Takala et al., 2014). On the other hand the lacks on data registration influence the outcome as well as the different criteria and registration requirements variation according to the countries (Saksvik \& Quinlan, 2003; Robson et al., 2007). Immigrants (Anastasiou, Siassiakos, Filippidis \& Nathanailides, 2015) are one of the most exposed social groups to diseases and accidents at work. Work-related diseases exert their influence not only through physical and psycho-social effects, but also in economic terms. General expenses, including medical expenses, loss of wages, loss of production and loosing because of disease-related causes such as pain and suffering, are very high (Leigh, Waehrer, Miller \& McCurdy, 2006; Tolbert et al., 2014).

Global trend of increasing retirement age has caused the increase of the workers exposure to the various harmful agents. In addition, due to industrialization, workers in developing countries are facing new working conditions for which they lack relevant knowledge (Hämäläinen, Saarela \& Takala, 2013). To understand the importance of safety and health at the national, regional or company base is required information for all stakeholders but primarily to healthcare professionals and employees at every level (Hämäläinen, Saarela \& Takala, 2009; Mendeloff \& Staetsky, 2014; ElMenyar, Mekkodathil \& Al-Thani, 2016; Rommel, Varnaccia, Lahmann, Kottner \& Kroll, 2016). Moreover, accurate information about health and safety at work and the use of smart systems for data control and storage enables the stakeholders in using them for all purposes. This information management system makes possible the efficiency use of it from the experts of the health and safety at work (Marchant et al., 2002).

Occupational medicine as an integral part of medical science should constitute one of the essential components of medical student education. Most of the health problems related to work are likely to be managed by not occupational medicine doctors (Yildiz, Bilir, Camur \& Caman, 2012; Smits \& Verbeek, 2015; van Dijk, Bubas \& Smits, 2015). Ignorance and bad management of work-related diseases are often associated with inadequate medical training (Baillargeon, Maheux \& Gilbert, 2011; Williams, Wynn \& Whitaker, 2011; Braeckman et al., 2013). Therefore, it is necessary that the knowledge of professionals about the health and safety at work ought to be updated not only with regard to the prevention, diagnosis and fighting the occupational diseases but also concerning the possible causal relationship between work and disease (Russ et al., 2012; van Dijk, Bubas, \& Smits, 2015). Moreover, they must recognize the fundamental legal aspects of their country 
(Sema \& Melo, 2012) as well as to the other industrialized (Saksvik \& Quinlan, 2003) or industrializing (Hämäläinen, Saarela \& Takala, 2013) countries. Increasing of the interest of medical students towards occupational medicine is certainly a challenge for many different reasons. Over the years, various bodies as well as national and international medical authorities have emphasized the importance of studying of the subject at medical university level (Shanahan, Lindemann \& Ahern, 2010; Yildiz, Bilir, Camur \& Caman, 2012; van Dijk, Bubas \& Smits, 2015). However, as appears from the literature, there are significant differences at national and international level regarding the length of the courses of occupational medicine, its content, and the examination procedures, suggesting that often occupational medicine is reduced and neglected (Bulat, 2008; Williams, Wynn \& Whitaker, 2011; Gehanno et al., 2014).

The low interest of healthcare professionals about occupational medicine can start from the low interest of the medicine students about it. This evidence the need to assess the attitudes of the students of medical sciences concerning the occupational medicine, in general, and as career chance; it results as insignificant career option for the medical sciences students (Russ et al., 2012). Improving of the quality of the occupational medicine will help in transforming the workplace in a better and safer place for the workers.

The presence of occupational medicine organizations (Ballester, Cordell, Jareño \& Serra, 2012) in the countries, for us, is an important indicator of the level of interest regarding this topic, but in Albania there is not an organization of any kind. Studies in which Albania it is involved have evidenced significant progress (http://www.ilo.org; http://www.euro.who.int) but also a number of health and safety problems in the areas of aquatic health, zoonotic diseases, and food safety (Coman et al., 2015). Completion of the legal framework for health and safety at work constitutes an important aspect of legislative activity in Albania (Sema \& Melo, 2012). In this context it is worth mentioning the Albanian government policy document concerning safety and health at work for the years 2016-2020 which aims to change many things in the country (http://www.sociale.gov.al).

\section{Method}

In our study we have chosen the method of an anonymous questionnaire, which was distributed to the third year students of Physiotherapy at the University Luigj Gurakuqi in Shkodra in their first lesson of Occupational Medicine. This Physiotherapy Faculty is the result of collaboration between the University of Shkodra and University of Florence (Italy). The course consists of 34 students but at the lesson were present 31 students, all over 18 years old. To the students was made clear that the participation was voluntary and they can even consign empty or incomplete 
questionnaires. All the students present in the lesson completed the questionnaire. We had a compiling percentage of $100 \%(31 / 31)$ and a participation rate (calculated by the total number of the course students) of $91 \%(31 / 34)$.

The questionnaire consists of 23 questions, some of which in the form of a 5 point Likert. The questionnaire was based on and adapted from previous works (Smits et al., 2012; Bhardwaj et al., 2015). In designing the questionnaire we started from the idea of what we like to know from our students and it consists mainly in two parts: some demographic data and the research data.

\section{Data collection and analyses}

Processing of questionnaires commenced with their numbering. For data analyzing it is been used the Excel software. There was build up a table in Excel where in each column were placed the questions and the response options while each row corresponds to a compiled questionnaire. In some cases in the questionnaires there are unanswered questions, this is reflected in the Excel table as "ABSENT". To better analyze the data, in Excel table, we set a filter system for each column. In data analyzing we calculated percentages of those who de facto answered the questions.

\section{Results}

\section{Demographic data}

The questionnaire was compiled by $23(74.2 \%)$ female and $8(25.8 \%)$ male students. The average age was 20.74 years old. All students declared that they completed the high school in 2013; in public schools 21 (67.7\%) students, and in private schools $10(32.3 \%)$ students.

In our study we have dedicated a special interest to the foreign languages that the students know without specifying the level of knowledge. It turns out that all students know at least one foreign language. Of which, 27 of them knows English, 28 students knows Italian, and 24 knows English + Italian. With only two foreign languages there are 17 students (the figure results in less than English + Italian, 24 students, because of the fact that most of the students who knows these two languages also declared to know other languages, too). With three foreign languages there are 6 students, and with more than three foreign languages there are 4 students.

\section{Research data}

In the group of research questions we asked them about the perception of the actuality of occupational medicine in general and in Albania, the perception of the occupational professional, the option of the occupational professional as choice of future career, their interest to study the problems of 
occupational medicine, their interest in having a master in this field, their perception regarding of work tasks of the occupational professional, and the relation of the physiotherapist profession with the occupational medicine.

Our research results are grouped as follows.

To understand the student's perception of the subject, the occupational medicine, we asked two questions in a 5 point Likert. Firstly, the need for the study of occupational medicine which got an average of 3.90 points out of 31 students, and, secondly, students have rated the level of their knowledge about the subject (remember that the questionnaire was distributed in the first lesson) in an average of 1.73 points from 30 students.

We got the student's perception of the actuality of occupational medicine in Albania through two questions in a 5 point Likert. In the first question we assessed the level of awareness about the occupational medicine in Albania resulting in a mean of 2.03 points from the responses of 31 students. While the second question was related to the law application of occupational medicine in country which resulted in a mean of 1.90 points out of 31 students answers.

To know the student's opinion concerning the perception of interest in occupational medicine in Albania we asked two questions. At the beginning we asked them if there is an increase in awareness about the occupational health in Albania in the last 5 years, resulting in $93.6 \%$ positive responses. The second question was about their opinion concerning the trend of occupational diseases in the future; $67.8 \%$ of students responded that occupational diseases will continue to be a medical problem for the future.

Seeking for the student's opinions about their perception of the relationship between the physiotherapist profession and the occupational medicine we asked them two questions. In the first question we asked them if they think that their profession is involved in occupational medical problems having a unanimous, $100 \%$, positive response. And in the second question, following this logic, we asked the students if the occupational medicine can be for them an employment option having a positive response from $58.6 \%$ of them.

When asking about their professional interest for future we presented three questions to the students. The first question was about the possibility of future training in this field of medicine resulting in a positive response from $75.9 \%$ of them. Moreover, $93.1 \%$ of students responded that the topic of inability to work is an interesting subject for study as well as for $90.3 \%$ of students the professional diseases are interesting to be studied, too.

For knowing their opinion regarding the work-related diseases we asked them four questions. According to the students, $73.3 \%$ of them, in each patient's disease may be work-related aspects. When asked about the return to work, $96.8 \%$ of students responded that the rehabilitation it is an important 
part of it. $90.3 \%$ of students stated that the doctors must report any suspected work disease and for $89.3 \%$ of the students in everyone health records should always be present the patient's profession.

The student's perception of the occupational professional work was: for $90.3 \%$ of them the occupational doctors play an important role in disease prevention, while $65.5 \%$ of the students stated that the occupational doctors working is composed of many administrative jobs.

Wanting to know the student's opinion for the mutual connection between work and diseases we posed a question to the students: "If you have a disease do you need to consider it when choosing a profession?", resulting in a positive response from $89.7 \%$ of them.

\section{Discussion}

\section{Demographic data}

We will begin our results discussion from foreign languages that the students stated to know. The situation appears good and we think that it is related to two reasons: the first is a general desire of Albanian students to learn foreign languages, starting from the fact that we are a small country and to communicate with foreigners we must know their language, or an international one. In another study completed with the pharmacists (Prendushi, 2016) we also found a good situation, too. Secondly, they are motivated by the fact that a large number of them, after the bachelor or the master, plan to immigrate outside Albania (from another yet unpublished study of the Author turns out that just $20 \%$ of the students of the same course after graduation will seek employment in Albania, 60\% abroad, mainly in the EU and USA, and $20 \%$ at all the options).

\section{Research data}

The level of interest expressed from the students regarding the subject of occupational medicine results adequate, 3.90 on a 5 point Likert. On the other hand it turns out that the course program for this subject is of only 10 hours, which appears to be at the minimum number of hours (average 25.5 hours) according to a study conducted in 135 universities in 27 EU countries (Gehanno et al., 2014). The students, 30 respondents, evaluate their knowledge about the occupational medicine, before the starting of the course, in a mean value of 1.73 points $(34.6 \%$ of the maximum assessment of the 5 point Likert). Very similar results are found in a study done in Brazil and Germany where values were below average points, $2.2 \pm 0.9$ (Russ et al., 2012), (36.7\% of the maximum assessment of the 6 point Likert). Also, in a study done in Turkey is shown that the student's initial level of knowledge of the subject was low (Yildiz, Bilir, Camur \& Caman, 2012). 
The perceiving of occupational medicine in Albania is 2.03, in a 5 point Likert, which is below the average. This is related to many factors; an important role may have the fact that even today in Albania doesn't exists a professional organization of occupational medicine professionals, while in the neighboring countries as Bosnia and Herzegovina, Croatia, Republic of Macedonia, and Serbia we find such professional organizations (Ballester, Cordell, Jareño \& Serra, 2012).

Regarding the implementation of the laws related to the health and safety at work in Albania the mean value taken from the students' responses it is even lower, 1.90 in a 5 point Likert. The legal framework of health and safety at work is generally defined, especially under the impulse of integration with the EU (http://www.sociale.gov.al), but in a number of important sectors of the economy there are gaps in the control and declaration of problems and accidents at work. This situation is also linked to the low level of awareness among employees and employers weak interest (http://www.ajls.org).

According to the students, 93.6\% of them, the interest about the occupational medicine in Albania actually is higher than 5 years ago. There is an increased attention regarding health and safety at work. Data from the literature confirm this trend. In 2008 were just 250 sanitary Inspectors (http://ishp.gov.al) in Albania while in the EU-funded project in 2015 were trained in collaboration with the International Labour Organization (ILO) 360 Labour Inspectors and over 220 National Employment Service staff (http://www.ilo.org).

At the other side, $67.8 \%$ of the respondents declare that the occupational diseases will continue to be a future medical problem. In a study in 188 countries for a period of 23 years, from 1990 to 2013, there was an increase of risk in general and the discovering of new risk factors (Forouzanfar, 2015). In a study about health and safety at work in Europe, the authors' advice that we should beware of false opinions about the good control of known risks as the globalization and the economic crisis are creating new risks (Gagliardi, Marinaccio, Valenti, \& Iavicoli, 2012).

Speaking about the relation between the physiotherapist profession and the occupational medicine all the students, $100 \%$, agree. Data from the literature confirm the very strong relation between the profession of occupational physician and physiotherapist (Poitras, Durand, Côté \& Tousignant, 2012), though doctor's work is primarily interested in the prevention of the diseases causes while the physiotherapist is interested in treatment/rehabilitation (https://www.physiotherapy.asn.au) of patients (De Wit et al., 2006; Moffett \& McLean, 2006; Kennedy et al., 2010; Adam, Strong \& Chipchase, 2014).

Furthermore, for $58.6 \%$ of students the occupational medicine is an employment option for them. In a study done in Brazil and Germany, unlike 
our results, it is shows that occupational medicine it is not considered as employment option from the students of the medicine faculties (Russ et al., 2012).

When speaking about the professional interests and future training it results that $75.9 \%$ of the students are interested in further training in this field of medicine. In a study done in Italy, in national level, it is shown that the doctors are wishing to update their knowledge about many aspects of their profession (Persechino et al., 2016). The literature shows that the study of issues (van Dijk, Bubas \& Smits, 2015) related to health and safety at work are needed to ensure a quality and effectiveness of services. Besides the need to study (World Health Organization, 1988) the use of new methods especially those of e-learning is proved to be effective (Hugenholtz, De Croon, Smits, Van Dijk \& Nieuwenhuijsen, 2008). Even in Albania in a study done with the pharmacists of Tirana it is shown that more than $30 \%$ of them would prefer short courses online as a way of study (Prendushi, 2016). In another study done by the Author (unpublished data) it is shown that $92 \%$ of students of physiotherapy after graduating want to continue the master studies. This trend is confirmed by other data (Petty, Scholes \& Ellis, 2011; Petty, Scholes \& Ellis, 2011).

Moreover, for $93.1 \%$ of students the topic of work disability is an interesting subject of study (Svendsen, Christiansen, Haahr, Andrea \& Frost, 2014; Clarke et al., 2016), as well as for $90.3 \%$ of the students the occupational diseases are interesting to study (Murtezani, 2012; Brattig, Schablon, Nienhaus \& Peters, 2014; Marks et al., 2014; O’Donoghue, Cunningham, Murphy, Woods \& Aagaard-Hansen, 2014; Alushllari \& Civici, 2015; Hodolli, Bekteshi, Kadiri, Xhafa, \& Dollani, 2015; Singla, Jones, Edwards \& Kumar, 2015; Kadiri, Hodolli, Nafezi, \& Dollani, 2016).

For the students, $73.3 \%$ of them, in each patient's disease may be workrelated aspects (Stern \& Madan, 2012), but not always appears that the GPs are prepared and know the problems associated with occupational diseases (Elms et al., 2005).

Regarding the return to work (Fylan, Gwynn \& Caveney, 2012), 96.8\% of students agree that the rehabilitation it is an important part of it.

$90.3 \%$ of students stated that the doctor must report any suspected work-related diseases (Hussey, Turner, Thorley, McNamee \& Agius, 2008; Morrison, 2011) and $89.3 \%$ of students agree that in all health records should always be shown the profession of the patient (Thorley, Turner, Hussey \& Agius, 2009; Hann \& Sibbald, 2013). However the data from literature shows that many GPs often do not take responsibility for managing work-related problems (Coole, Watson \& Drummond, 2010).

For $90.3 \%$ of students the occupational professionals play an important role in the prevention, diagnosis and treatment of occupational diseases. 
Similar results were obtained, also, in a study in Turkey (Yildiz, Bilir, Camur \& Caman, 2012). While for $65.5 \%$ of the students the occupational professional work is composed of many administrative jobs.

Looking to know the perceived relation from the students between work and disease it results that for $89.7 \%$ of them it is clear that before deciding e career they have to consider any disease that they may have. The literature describes thoroughly this argument (Beatty \& Joffe, 2006; Beatty, 2012; Kunnen, 2014; McGonagle \& Barnes- Farrell, 2014).

\section{Limitations}

The main limitation of our study is the reduced number of students determined by the dimensions of the physiotherapy course. On the other hand there is a small possibility, but the questionnaire was anonymous, that any student, in any question, answered as to satisfy the professor.

\section{Conclusion}

We have a very positive situation regarding the foreign languages.

Students positively evaluate the study of occupational medicine.

The awareness about occupational medicine in Albania results low but it is better than 5 years ago.

Students of physiotherapy unanimously are expressed that there are strong relations between their profession and the occupational medicine.

For more than one half of the students the occupational medicine is a career option given that the majority of them believe that work-related diseases and injuries will continue to exist.

Over $75 \%$ of students are interested in further training as well as for more than $90 \%$ of them the topics of work diseases and inability to work are interesting to be studied.

Students always state that family doctors should report suspicions regarding occupational diseases and the profession of the patient should always be in his medical records.

\section{Acknowledgement}

I thank my students for having filled out the questionnaire.

\section{References:}

1. Adam, K., Strong, J., \& Chipchase, L. (2014). Readiness for work injury management and prevention: important attributes for early graduate occupational therapists and physiotherapists. Work, 48(4), 567-578. 
2. Alushllari, M., \& Civici, N. (2015). Verification of Penetration of Lead in the Profile of Soil around the Former Battery Production Factory, Berat Albania. Journal of Environmental Protection, 6(04), 388.

3. Anastasiou, S., Siassiakos, K., Filippidis, K., \& Nathanailides, C. (2015). Occupational Accidents of Immigrant Workers in Greece. Procedia Economics and Finance, 33, 226-233.

4. Baillargeon, M., Maheux, B., \& Gilbert, A. (2011). The challenge of teaching occupational medicine to medical students: the Université de Montréal experience. Journal of Occupational and Environmental Medicine, 53(11), 1258-1261.

5. Ballester, M., Cordell, N., Jareño, M. R., \& Serra, C. (2012). A European survey of professional bodies representing occupational medicine specialists. Occupational medicine, 62(5), 366-370.

6. Beatty, J. E., \& Joffe, R. (2006). An Overlooked Dimension Of Diversity:: The Career Effects of Chronic Illness. Organizational Dynamics, 35(2), 182-195.

7. Beatty, J. E. (2012). Career barriers experienced by people with chronic illness: A US study. Employee Responsibilities and Rights Journal, 24(2), 91-110.

8. Bhardwaj, M., Arteta, M., Batmunkh, T., Leonardo, L. B., Caraballo, Y., Carvalho, D., ... \& Ilse, U. (2015). Attitude of medical students towards occupational safety and health: a multi-national study. The international journal of occupational and environmental medicine, 6(1 January), 488-7.

9. Braeckman, L., De Clercq, B., Janssens, H., Gehanno, J. F., Bulat, P., Pauncu, E. A., ... \& Valcke, M. (2013). Development and evaluation of a new occupational medicine teaching module to advance selfefficacy and knowledge among medical students. Journal of Occupational and Environmental Medicine, 55(11), 1276-1280.

10. Brattig, B., Schablon, A., Nienhaus, A., \& Peters, C. (2014). Occupational accident and disease claims, work-related stress and job satisfaction of physiotherapists. Journal of Occupational Medicine and Toxicology, 9(1), 1.

11. Bulat, P. (2008). Occupational medicine in the basic curriculum. $T B V$ Tijdschrift voor Bedrijfs-en Verzekeringsgeneeskunde, 16(10), 432436. 
12. Clarke, C. E., Patel, S., Ives, N., Rick, C. E., Woolley, R., Wheatley, K., .. \& Sackley, C. M. (2016). Clinical effectiveness and costeffectiveness of physiotherapy and occupational therapy versus no therapy in mild to moderate Parkinson's disease: a large pragmatic randomised controlled trial (PD REHAB). Health Technology Assessment, 20(63), 1-96.

13. Coman, A., Cherecheş, R. M., Ungureanu, M. I., Marton-Vasarhelyi, E. O., Valentine, M. A., Sabo-Attwood, T., \& Gray, G. C. (2015). An assessment of the occupational and environmental health needs in seven Southeastern European and West-Central Asian countries. Journal of epidemiology and global health, 5(4), 375-384.

14. Coole, C., Watson, P. J., \& Drummond, A. (2010). Work problems due to low back pain: what do GPs do? A questionnaire survey. Family practice, 27(1), 31-37.

15. De Wit, L., Putman, K., Lincoln, N., Baert, I., Berman, P., Beyens, H., ... \& De Weerdt, W. (2006). Stroke Rehabilitation in Europe What Do Physiotherapists and Occupational Therapists Actually Do?. Stroke, 37(6), 1483-1489.

16. El-Menyar, A., Mekkodathil, A., \& Al-Thani, H. (2016). Occupational injuries: Global and local perspectives. Nepal Journal of Epidemiology, 6(2), 560-562.

17. Elms, J., O'Hara, R., Pickvance, S., Fishwick, D., Hazell, M., Frank, T., ... \& Harvey, P. (2005). The perceptions of occupational health in primary care. Occupational Medicine, 55(7), 523-527.

18. Forouzanfar, M. H., Alexander, L., Anderson, H. R., Bachman, V. F., Biryukov, S., Brauer, M., ... \& Delwiche, K. (2015). Global, regional, and national comparative risk assessment of 79 behavioural, environmental and occupational, and metabolic risks or clusters of risks in 188 countries, 1990-2013: a systematic analysis for the Global Burden of Disease Study 2013. The Lancet, 386(10010), 2287-2323.

19. Fylan, F., Gwynn, B. F., \& Caveney, L. (2012). GPs’ perceptions of potential services to help employees on sick leave return to work. $U K$ : Department for Work \& Pensions.

20. Gagliardi, D., Marinaccio, A., Valenti, A., \& Iavicoli, S. (2012). Occupational safety and health in Europe: Lessons from the past, 
challenges and opportunities for the future. Industrial health, 50(1), 711.

21. Gehanno, J. F., Bulat, P., Martinez-Jarreta, B., Pauncu, E. A., Popescu, F., Smits, P. B. A., ... \& Braeckman, L. (2014). Undergraduate teaching of occupational medicine in European schools of medicine. International archives of occupational and environmental health, 87(4), 397-401.

22. Hämäläinen, P., Saarela, K. L., \& Takala, J. (2013). Global estimates of fatal work-related diseases by region and disease group, 2002. International journal of occupational and environmental health.

23. Hämäläinen, P., Saarela, K. L., \& Takala, J. (2009). Global trend according to estimated number of occupational accidents and fatal work-related diseases at region and country level. Journal of safety research, 40(2), 125-139.

24. Hann, M., \& Sibbald, B. (2013). General Practitioners' attitudes towards patients' health and work, 2010-12.

25. Hodolli, G., Bekteshi, S., Kadiri, S., Xhafa, B., \& Dollani, K. (2015). Radon concentration and gamma exposure in some Kosovo underground mines. INTERNATIONAL JOURNAL OF RADIATION RESEARCH, 13(4), 369-372.

26. Hugenholtz, N. I., De Croon, E. M., Smits, P. B., Van Dijk, F. J., \& Nieuwenhuijsen, K. (2008). Effectiveness of e-learning in continuing medical education for occupational physicians. Occupational Medicine, 58(5), 370-372.

27. Hussey, L., Turner, S., Thorley, K., McNamee, R., \& Agius, R. (2008). Work-related ill health in general practice, as reported to a UK-wide surveillance scheme. Br J Gen Pract, 58(554), 637-640.

28. Kadiri, S., Hodolli, G., Nafezi, G., \& Dollani, K. (2016). Assessment of Beam Quality in Some Radio Diagnostic Centers. Journal of Chemical, Biological and Physical Sciences (JCBPS), 6(4), 1217.

29. Kennedy, C. A., Amick III, B. C., Dennerlein, J. T., Brewer, S., Catli, S., Williams, R., ... \& Franzblau, A. (2010). Systematic review of the role of occupational health and safety interventions in the prevention of upper extremity musculoskeletal symptoms, signs, disorders, injuries, claims and lost time. Journal of occupational rehabilitation, 20(2), 127-162. 
30. Kunnen, E. S. (2014). The effect of a career choice guidance on selfreported psychological problems. Frontiers in psychology, 5.

31. Leigh, J. P., Waehrer, G., Miller, T. R., \& McCurdy, S. A. (2006). Costs differences across demographic groups and types of occupational injuries and illnesses. American journal of industrial medicine, 49(10), 845-853.

32. Manickam, K., Jin, T. W., Heng, P., Tjong, C., Kheng, L. G., Lim, S., \& Lin, G. S. (2014). Global Estimates of the Burden of Injury and lllness at Work. Journal of Occupational and Environmental Hygiene, 11, 1-12.

33. Marchant, G. E., Amen, M. A., Bullock, C. H., Carter, C. M., Johnson, K. A., Reynolds, J. W., ... \& Crane, A. E. (2002). A synthetic vitreous fiber (SVF) occupational exposure database: Implementing the SVF health and safety partnership program. Applied occupational and environmental hygiene, 17(4), 276-285.

34. Marks, D., Bisset, L., Thomas, M., O’Leary, S., Comans, T., Ng, S. K., .. \& Scuffham, P. (2014). An experienced physiotherapist prescribing and administering corticosteroid and local anaesthetic injections to the shoulder in an Australian orthopaedic service, a noninferiority randomised controlled trial and economic analysis: study protocol for a randomised controlled trial. Trials, 15(1), 1.

35. McGonagle, A. K., \& Barnes-Farrell, J. L. (2014). Chronic illness in the workplace: Stigma, identity threat and strain. Stress and Health, 30(4), 310-321.

36. Mendeloff, J., \& Staetsky, L. (2014). Occupational fatality risks in the United States and the United Kingdom. American journal of industrial medicine, 57(1), 4-14.

37. Moffett, J., \& McLean, S. (2006). The role of physiotherapy in the management of non-specific back pain and neck pain. Rheumatology, 45(4), 371-378.

38. Morrison, J. (2011). The role of the GP in keeping people in work. Occupational medicine, 61(2), 74-75.

39. Murtezani, A. (2012). Low back pain among Kosovo power plant workers: a survey. Italian Journal of Public Health, 9(4).

40. O’Donoghue, G., Cunningham, C., Murphy, F., Woods, C., \& Aagaard-Hansen, J. (2014). Assessment and management of risk 
factors for the prevention of lifestyle-related disease: a cross-sectional survey of current activities, barriers and perceived training needs of primary care physiotherapists in the Republic of Ireland. Physiotherapy, 100(2), 116-122.

41. Persechino, B., Fontana, L., Buresti, G., Rondinone, B. M., Laurano, P., Imbriani, M., \& Iavicoli, S. (2016). Professional Activity, Information Demands, Training and Updating Needs of Occupational Medicine Physicians in Italy: National Survey. International journal of occupational medicine and environmental health, 29(5), 837-858.

42. Petty, N. J., Scholes, J., \& Ellis, L. (2011). Master's level study: learning transitions towards clinical expertise in physiotherapy. Physiotherapy, 97(3), 218-225.

43. Petty, N. J., Scholes, J., \& Ellis, L. (2011). The impact of a musculoskeletal masters course: developing clinical expertise. Manual therapy, 16(6), 590-595.

44. Poitras, S., Durand, M. J., Côté, A. M., \& Tousignant, M. (2012). Guidelines on low back pain disability: interprofessional comparison of use between general practitioners, occupational therapists, and physiotherapists. Spine, 37(14), 1252-1259.

45. Prendushi, H. (2016). The Attitudes and Practices of Albanian Pharmacists Regarding Complementary Medicinal Products and Supplements. Imperial Journal of Interdisciplinary Research, 2(8).

46. Retrieved on 10 October 2016: http://www.ilo.org/global/about-theilo/newsroom/news/WCMS_211627/lang--en/index.htm

47. Retrieved on 10 October 2016: http://www.ilo.org/safework/countries/europe/albania/WCMS_18788 6/lang--en/index.htm

48. Retrieved on

$10 \quad$ October

2016:

http://www.euro.who.int/_data/assets/pdf_file/0015/117060/E94072 .pdf

49. Retrieved

on

10

October

2016: http://www.sociale.gov.al/files/documents_files/English_Final_Versi on_for_publishing_OSH_policy_doc.pdf

50. Retrieved on 10 October 2016: http://www.ajls.org/doc/6_ESema_Pergjegjesia_Ligjore_Punedhenes it.pdf 
51. Retrieved

on

10

October

2016:

http://ishp.gov.al/docs/DESiSH/sherbimet/Studimi\%20mbi\%20Nevoj at\%20per\%20Trajnim\%20Shendet\%20Publik\%20ne\%20Shqiperi\%2 0_\%202008\%20_\%20ENG.pdf

52. Retrieved on 10

October

2016:

http://www.ilo.org/budapest/information-resources/pressreleases/WCMS 339103/lang--en/index.htm

53. Retrieved on 10

October

2016:

https://www.physiotherapy.asn.au/DocumentsFolder/APAWCM/Adv ocacy/PositionStatement_2017_Thephysiotherapist\%E2\%80\%99s_ro le_occ_rehabilitation.pdf

54. Robson, L. S., Clarke, J. A., Cullen, K., Bielecky, A., Severin, C., Bigelow, P. L., ... \& Mahood, Q. (2007). The effectiveness of occupational health and safety management system interventions: a systematic review. Safety Science, 45(3), 329-353.

55. Rommel, A., Varnaccia, G., Lahmann, N., Kottner, J., \& Kroll, L. E. (2016). Occupational Injuries in Germany: population-wide national survey data emphasize the importance of work-related factors. PloS one, $11(2)$, e0148798.

56. Russ, P., Strümpell, S., Carvalho, D., Zander, S., Smits, P., Nowak, D., \& Radon, K. (2012). Compulsory teaching of occupational health: impact on attitude of medical students in Brazil and Germany. International archives of occupational and environmental health, 85(1), 81-87.

57. Saksvik, P. Ø., \& Quinlan, M. (2003). Regulating systematic occupational health and safety management: comparing the Norwegian and Australian experience. Relations Industrielles/Industrial Relations, 33-59.

58. Sema, E., \& Melo, I. (2012). Health and safety at work.

59. Shanahan, E. M., Lindemann, I., \& Ahern, M. J. (2010). Engaging medical students in occupational and environmental medicine-a new approach. Occupational medicine, 60(7), 566-568.

60. Singla, M., Jones, M., Edwards, I., \& Kumar, S. (2015). Physiotherapists' assessment of patients' psychosocial status: Are we standing on thin ice? A qualitative descriptive study. Manual therapy, 20(2), 328-334. 
61. Smits, P. B. A., De Graaf, L., Radon, K., De Boer, A. G., Bos, N. R., van Dijk, F. J. H., \& Verbeek, J. H. A. M. (2012). Case-based elearning to improve the attitude of medical students towards occupational health, a randomised controlled trial. Occupational and environmental medicine, 69(4), 280-283.

62. Smits, P. B. A., \& Verbeek, J. H. A. M. (2015). A questionnaire to measure medical students' attitudes towards occupational medicine. Occupational Medicine, kqv055.

63. Stern, A. F., \& Madan, I. (2012). Optimal communication from occupational physicians to GPs: a cross-sectional survey. $\mathrm{Br} \mathrm{J}$ Gen Pract, 62(605), e833-e839.

64. Svendsen, S. W., Christiansen, D. H., Haahr, J. P., Andrea, L. C., \& Frost, P. (2014). Shoulder function and work disability after decompression surgery for subacromial impingement syndrome: a randomised controlled trial of physiotherapy exercises and occupational medical assistance. BMC musculoskeletal disorders, 15(1), 1.

65. Takala, J., Hämäläinen, P., Saarela, K. L., Yun, L. Y., Manickam, K., Jin, T. W., ... \& Lin, G. S. (2014). Global estimates of the burden of injury and illness at work in 2012. Journal of occupational and environmental hygiene, 11(5), 326-337.

66. Thorley, K., Turner, S., Hussey, L., \& Agius, R. (2009). Continuing professional development in occupational medicine for general practitioners. Occupational medicine, 59(5), 342-346.

67. Tolbert, D. V., McCollister, K. E., LeBlanc, W. G., Lee, D. J., Fleming, L. E., \& Muennig, P. (2014). The economic burden of disease by industry: Differences in quality-adjusted life years and associated costs. American journal of industrial medicine, 57(7), 757-763.

68. van Dijk, F. J., Bubas, M., \& Smits, P. B. (2015). Evaluation studies on education in occupational safety and health: inspiration for developing economies. Annals of global health, 81(4), 548-560.

69. van Dijk, F. J., Verbeek, J. H., Hoving, J. L., \& Hulshof, C. T. (2010). A knowledge infrastructure for occupational safety and health. Journal of occupational and environmental medicine, 52(12), 1262-1268. 
70. Williams, N., Wynn, P. A., \& Whitaker, S. (2011). Undergraduate occupational medicine tuition in UK schools of medicine. Occupational medicine, 61(3), 152-156.

71. World Health Organization. (1988). Training and education in occupational health: report of a WHO study group [meeting held in Geneva from 24 to 28 November 1986].

72. Yildiz, A. N., Bilir, N., Camur, D., \& Caman, O. K. (2012). Evaluation of occupational health teaching sessions for final year medical students. Safety and health at work, 3(2), 123-129. 